Historic, Archive Document

Do not assume content reflects current scientific knowledge, policies, or practices. 

G.v $\quad 62,27$

$\sin 55$

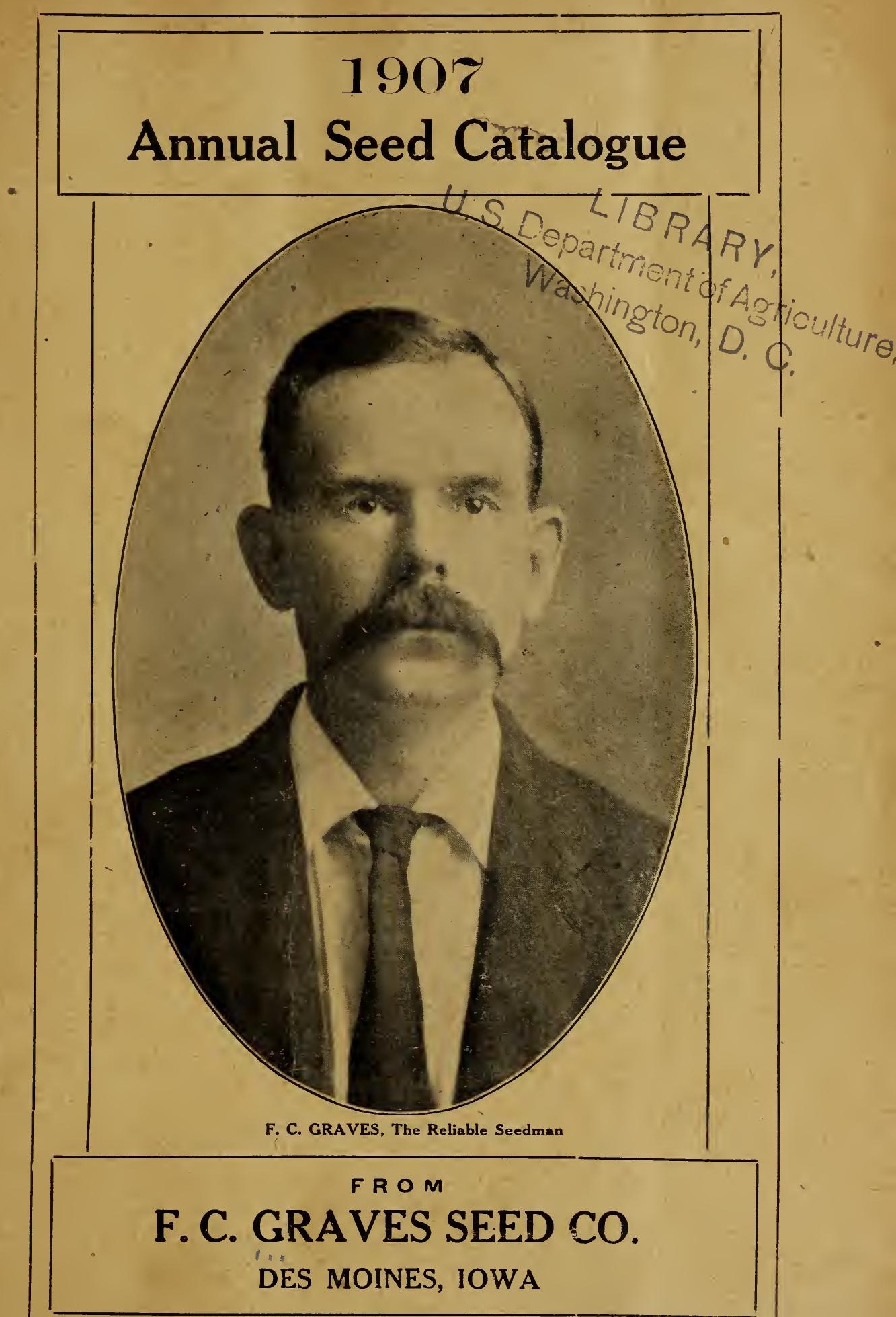




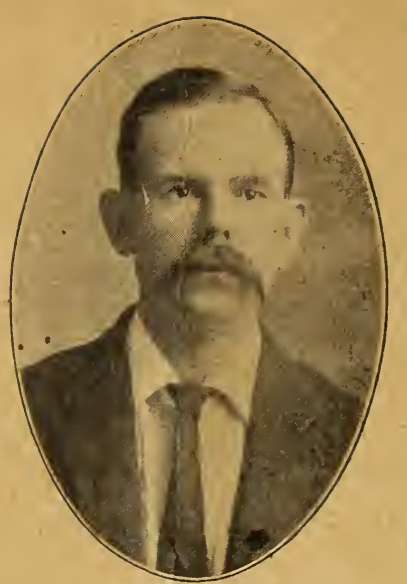

F. C. GRAVES.

\section{Ft Drosperous thew Wear \\ to Jfriends and}

\section{Customers.}

We again take great pleasure in mailing * you our 1907 seed catalogue, knowing well your preference of doing business direct with the grower, who can supply you with better seeds at much lower prices than can be quoted by other firms, thereby saving you the retailer's profit. Yours truly,

\section{F. G. Graves Seed Go.}

The prices made in this list cannot be beat by any other seed house and considering the quality of our goods it will be money in your pocket to place your seed order with us. A trial order will make you a sure customer, assuring you that any orler or inquiry received will have prompt and careful attention.

Our railroad facultios are such that we can handle orders with a promptness that is bound to satisfy our customers.

TERMS: We pay postage on packages, ounces and oneour expense, add to the rate of $10 \mathrm{c}$ per pound and $15 \mathrm{c}$ per quart to pay postage. Cash must accompany order when sent

Q through the mail. Remittance may be madé by stamps, P. O. Oz̧der, Draft, Express Order or Registered Letter.

Special terms to Market Gardners.

We ask you to kindly look the following price list over carefully. We are sure you will find something that will be of interest to you.

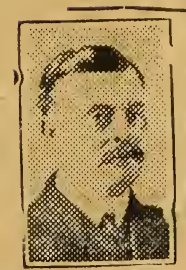

\section{Get Well! Others Have! You Can!}

I treat chronic cases right and for rates that are right land just. I want to help you so that you can help me. I do not misrepresent conditions I find present. If I think I can not help you I say so. I treat each case according to its needs, not always the right way I use any and every means modern or ancient it matters not to me so it cures patients. Eiectricity, dry heat, masgage, the X-Ray, compound air, these are a few of the means I use. I am a physician and use drugs or operative measures whenever they are needed. I do not expect you to get well on moonshine furnished by yourself and then pay me for it. But my medicines are modern and pleasant in action. Give my attention to diseases of the nervous system. Catarrh and all chronic troubles.

Examination Free! Treatment by the month within the reach of any one who needs it. in the neighborhood at reasonable rates. Office open evenings and Sunday forenoons. Free $\mathrm{X}-\mathrm{Kay}$ demonstrations evenings. Write today for free booklet if you cannot call.

W. G. MORGAN, M. D,

623 Walnut St. (Cor. 7th.) The corner east of Younker's. Mutual Telephone at office and residence, 


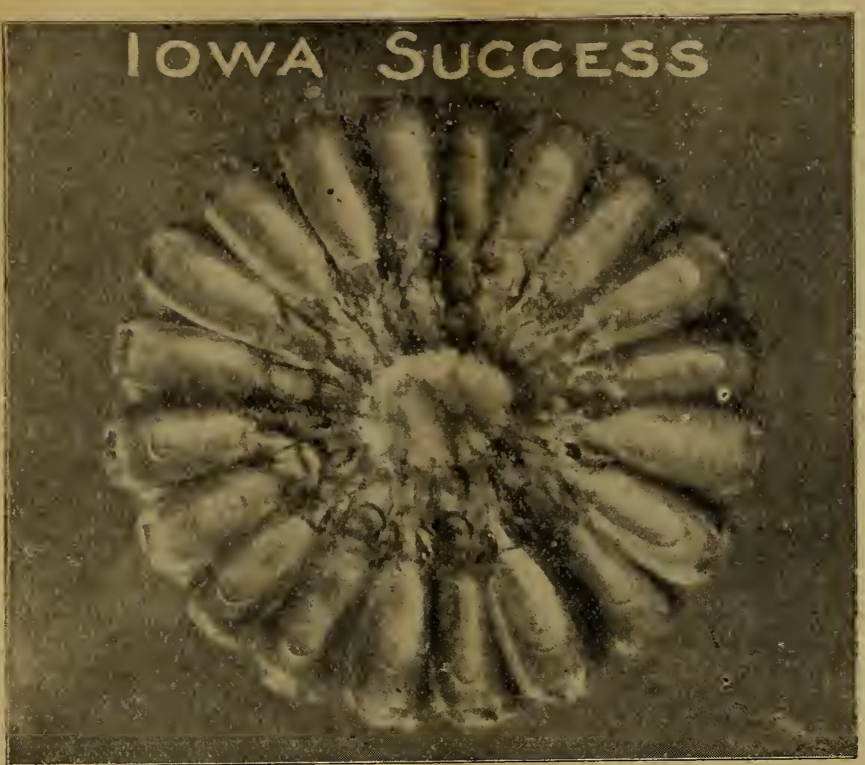

lowa grown Seed Corn

\section{Tested and war- ranted 98 per cent.}

IOWA SUCCESS is one of Iowa's greatest introductions as a corn, Ears large having from 18 to 20 rows on the cob; 62 pounds of corn and 8 pounds of cobs, 2 and 3 ears on stalk; 1.311 bushels of corn grown on ten acres in 1906 in Story county in the Indian Creek bottom. Try it this year. Price, packet 2c, quart $25 \mathrm{c}$. peck $75 \mathrm{c}$, half bushel $\$ 1.25$, bushel $\$ 2.00$. Sacks free.

\section{A FEW POINTERS ON SEED CORN}

There is no crop on which the farmer depends more for results than the corn crop. Care should be taken to have all conditions favorable. Above all you must have good seed. No matter how good the land or how favorable the weather, if the seed is poor, it is time and money wasted.

The varieties listed here are especially adapted to Iowa, Nebraska, Missouri and Illinois. Of course, certain ones can be grown in certain parts of the corn belt to better advantage. Information in this regard will be cheerfully given.

Our stock of seed corn this year is very choice. It is all carefully selected and tested, showing high germa rating qualities. If you desire to learn further the merits of our seed corn, we should be glad to hear from you, assuring you that ali inquiries will receive careful and prompt attention.

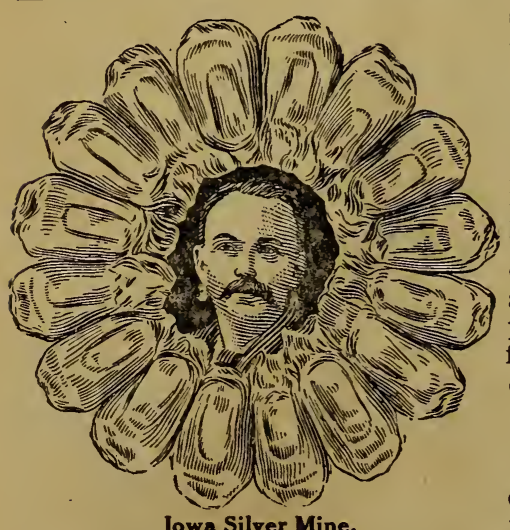

\section{IOWA SILVER MINE}

One of the greatest white corn known to exist; 215 bushels has been grown per acre. You may doubt this statement, but $\mathrm{Mr}$. Claus. Jochinson, a well-to-do German farmer of Scott county, Iowa, grew it. Ears large, deep grain, color very bright, pearl white. This corn will produce a crop where others fail. You won't miss it by planting a few acres this season. Price, packet 5c, pound $25 \mathrm{c}$, three pounds $50 \mathrm{c}$, by mail; by freight peck, 50c, bushel, $\$ 1.75$, five bushels at $\$ 1.60$ per bushel.

\section{PRIDE OF THE NORTH}

This variety originated with A. L. Goddard, of Kossuth county, Iowa, about twenty years ago and sprang at once into promin. ence as the earliest of all Yellow Dent corn. Price by mail 5c, pound 20c, three pounds $40 \mathrm{c}$, half bushel $65 \mathrm{c}$, bushel at $\$ 1.10$, three to five bushels at $\$ 1.00$. 


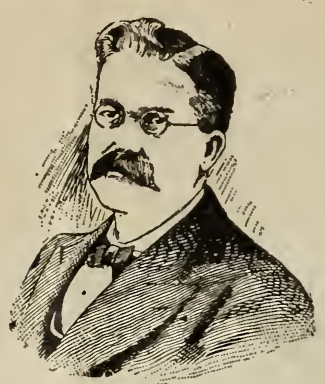

\section{For Twenty Years a Specialist}

I have sucessfully treated all forms of Chronic Diseases: such as Kidney, Bladder, Heart Blood and Womanly diseases; Piles, Dyspepsia, Deafness, Rheumatism, Constipation, Varicocele, Hydrocele and Rupture.

If you are tired of paying out money and receiving no benefit. write to me for mv symptom blank. I will then tell you, free of charge. what I think can be done for you and will give you my honest opinion, backed up by a larxe experience, as to what you should do. You will not be under any obligation, whatever, to treat with me unless you so wish and I will tell you just what it will cost you. If you will tell me your most prominent symptoms 1 will send you a trial treatment.

707 Iowa Loan and Trust Building.

\section{F. M. McCanon, M. D., Specialist,}

Extracts From a Few Letters on File. Names Furnished to Those Interested.

Please accept my sincere thanks for the restoration of my wife from a broken down woman to one of almost perfect health.

- E. A.

You do not know how much better 1 am feeling. I believe you did not miss it when you said I would some day be one of the happiest girls living.

I thihk your $n$ edicine has done me a world of good.

Not a day passes but that I am grateful for what you have done for me - Miss Nellie B.

I think I have better health now than I ever did. I am feeling so well and strong and will always remember what you have done for me. -Mrs. E. H. A.

I am feeling real good. Your medicine has helped me so much and you will find enclosed a money order for anot er month's treatment.

- Mrs. Chas. W.

I am feeling so much better, I can walk and get about as well as ever, so far as rheumatism is concerned. Please send me another month's supply of remedies.

\section{IOWA GOLD MIN E}

\section{Best Variety of Yellow Corn in the World.}

Every one who has tried it is enthusiastic in the praise of this splendid new variety, which was introduced in 1892. Iowa is not called a gold mine state, but in this grand new variety farmers of this country will find a veritable mine of wealth.
It has received the most cordial endorsement as the best and most profitable variety ever grown. Price, packet $5 \mathrm{c}$, one pound $25 \mathrm{c}$, three pounds $60 \mathrm{c}$ by mail postpaid. By freight, peck 50 c, bushel $\$ 1.50$, in 8 and 10 bushel lots at $\$ 1.40$ per bu.

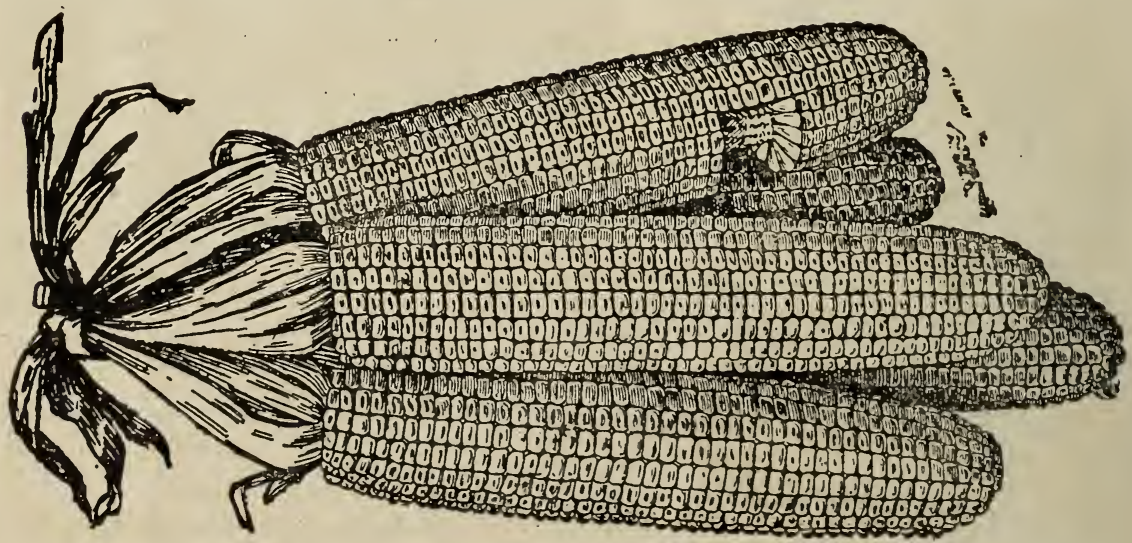




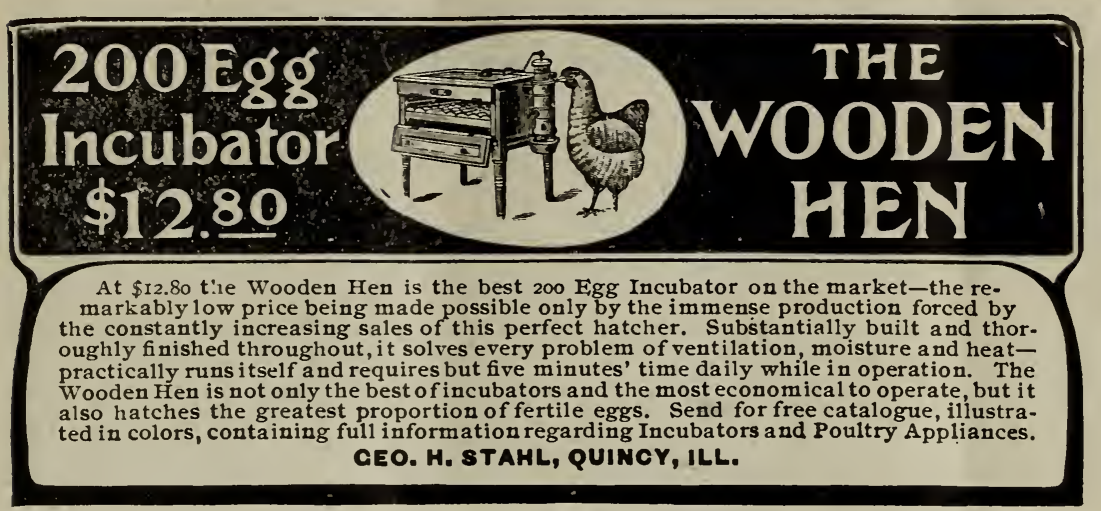

\section{Grass Seeds}

Fall is the best time to sow most kinds of grass seeds-it is nature's season. Clover. however, usually does better sown in the spring. For many years we have made a

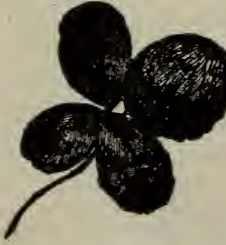

Clover Seeds.

Choice Clover, per bu. .......\$7.60 Prime Clover, per bu. ........ 7.50 Mammoth Clover, per bu....... 9.85 White Dutch, per lb.......... .18 Choice Alfalfa, per bu........ 8.20 Choice Alsyke, per bu........ 8.25 Special rrices on large quantities.

\section{Grass Seeds.}

Kentucky Blue Grass...........

$\ldots \ldots \ldots$ tb $15 \mathrm{c} 2$ \&s $25 \mathrm{c}$ bu $\$ 1.40$

Stripped Blue Grass............

$\ldots \ldots \ldots$ tb $10 \mathrm{c} 3$ tbs $25 \mathrm{c}$ bu. $\$ 1.20$

Timothy, best on market ....bu. $\$ 1.45$

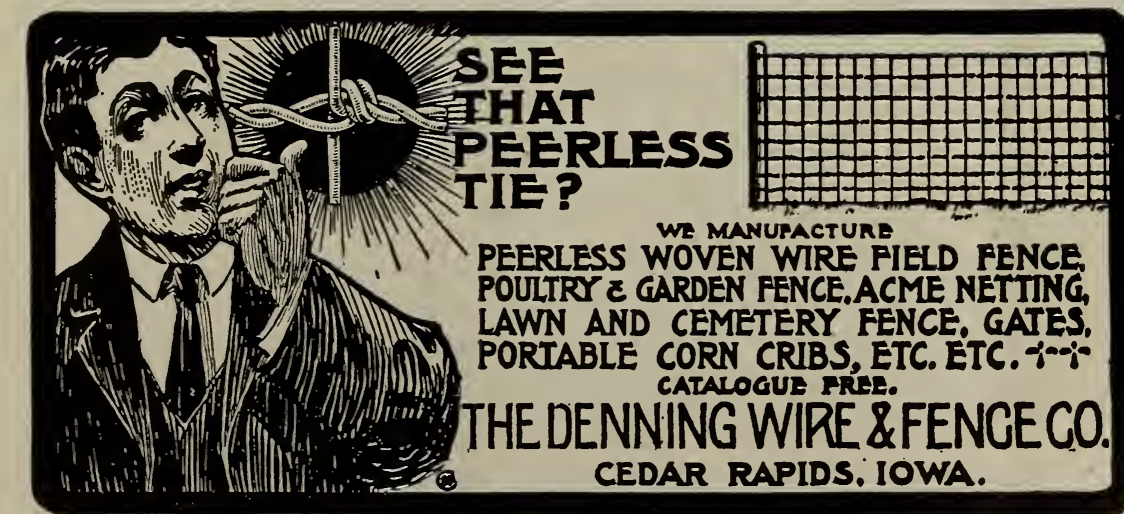

Lawn Grass (sp'l mixed) ........

$\ldots \ldots \ldots \ldots \ldots$ to $18 \mathrm{c} 3$ ths $50 \mathrm{c}$

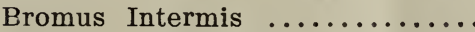

$\ldots \ldots$ tb $15 \mathrm{c} 2$ \&s $25 \mathrm{c}$ bu. $\$ 1.75$

Miscellaneous Field Seeds.

Rape Dwf Essex ............. tb $8 \mathrm{c} 5$ tbs $35 \mathrm{c} 10$ tb $60 \mathrm{c}$ Cane, Early Amber..Write for prices Kaffir Corn, White. $1 / 4$ bu 35c bu $\$ 1.00$ Millet, German......Write for prices Millet, common......Write for prices Field Peas, White Canada......

$$
\text { ........... 1/4 bu 55c bu } \$ 2.05
$$

Soga Beans .....1/4 bu $75 \mathrm{c}$ bu 2.35 


\section{SEED OATS}

Irish Victor.

Introduced by the Iowa Seed Company. A grand variety and the most productive variety ever brought out. It is probably known to but few farmers that almost all the new varieties of oats originated either in Scotland, Northern Ireland, or New Zealand. You had better put out a field of them this year. By mail, packet, $5 \mathrm{c}$, pound $20 \mathrm{c}$, three pounds 50 c; by freight, peck 40c, bushel 95c, five bushels $80 \mathrm{c}$, ten bushels at $65 \mathrm{c}$, thirty bushels at 60c. Sacks free.

\section{Early Champion Oats.}

This grand new variety, which was introduced by us in 1897, has given excellent satisfaction to our customers. Try a few bushels this season; packet $5 \mathrm{c}$, pound $15 \mathrm{c}$, three pounds $40 \mathrm{c}$ by mail; by freight, peck

$35 c$, half bushel $60 c$, bushel $90 c$, two bushels or more at $80 \mathrm{c}$, ten bushels or more at 70c. Sacks free.

\section{Lincoln Oats.}

Seven prizes awarded in 1900 to farmers who grew the most bushels of oats sown. First prize going to a man who grew 174 bushels from one bushel of seed sown; six others averages were 116 bushels from one sown. By freight, sacks free, peck $35 c$, bushels $90 \mathrm{c}$, two bushels or more at $80 \mathrm{c}$, ten bushels or more at $70 \mathrm{c}$, thirty bushels at $65 \mathrm{c}$.

\section{Silver Mine Oats.}

A very popular variety in some sections and said to yield immense crops. Our seed is pure and choice. Peck 30c, bushel $80 c$, two bushels or more at $70 \mathrm{c}$, five bushels or more at $65 c$, ten bushels or more at $60 c$, thirty bushels at $50 \mathrm{c}$. 


\section{Rheumatism Cured}

\section{I hear vou say, the old story "Quack, Quack," but Stop! Look! Listen!}

For twenty-five years was owner and manager of the Ryan Sanitarium at Colfax, Iowa, where I successfully treated hundreds of rheumatism patients, as well as stomach, liver, kidneys and bladder diseases. My time being too short to allow my rheumatic specific and other remedies found out by mere accident, I therefore use printer's ink for one time only. I know anyone cin advertise. Anyone can get testimonials. But forty-five years of experience with my unlimited advanteges and experience will most like$1 y$ cause the most skeytical to think for one or two minutes. This is my first and last ad. If interested send me $\$ 2.00$ for trial bottle. If not satisfied tell your friends if my statement is true or false. Tell everybody.

\section{J. R. RYAN, M. D.,}

Good Block, Des Moines, lowa.

\section{PENGILLARIA \\ A WONDERFUL NEW FODDER PLANT \\ "Pencillaria" the greatest of fodder plants. It is simply a twentieth century wonder and when cut and shocked it looks as if the shocks half covered the ground. It is the most productive hay and fodder plant in cultivation. This plant is worthy of the careful consideration of every pro- gressive farmer, dairyman, stockman and poultryman in the country. 'This is a native of Central America and the tropics, but has been tried in this country to such an extent that it can be ranked as one of the most valuable plants that can be grown for fodder, hay or ensilage. It is a new fodder plant and it is creating a great sensation in its mar- velous productiveness and wonderful qualities, It is an annual, producing a heavy growth of broad, dark green leaves, closely resembling common corn. It should be sown very thin as it stnols out like wheat. It grows faster and taller .han any fodder we ever saw and while we did not measure the yield it was enormous. Like Cane or Kaffir corn, it does not blow down and is not affected by dry weather. It can be cut several times like Alfalfa and there is no exaggeration in saying that five to fifteen tons per acre could easily be secured every year. Take our word for it and grow some and you will thank us for urg- ing you. Do not plant until the ground is warm and one pound will plant an acre. Price-By mail, postpaid,} ounce, $10 \mathrm{c}$; $\frac{1}{4}$ pound, $30 \mathrm{c} ; 1$ pound, $75 \mathrm{c}$; write for prices on larger quantities.
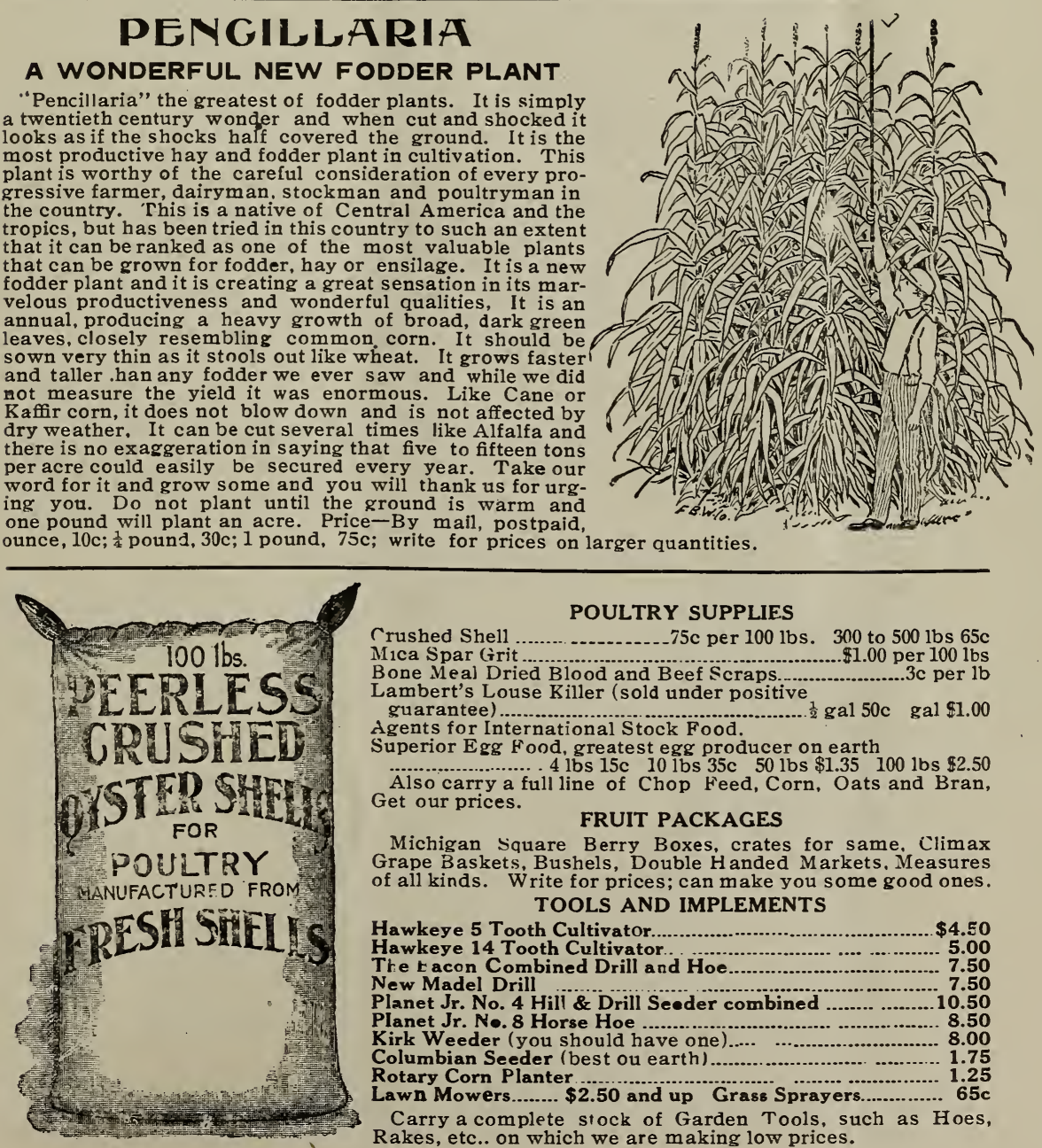

\section{POULTRY SUPPLIES}

Crushed Shell .................. 75c per $100 \mathrm{lbs.} 300$ to $500 \mathrm{lbs} 65 \mathrm{c}$ Mica Spar Grit $\$ 1.00$ per 100 lbs Bone Meal Dried Blood and Beef Scraps.......................3c per 1b Lambert's Louse Killer (sold under positive guarantee)

dgents for International Stock Food.

Superior Egg Food, greatest egg producer on earth

Ai................... 4 lbs $15 \mathrm{c} 10 \mathrm{lbs} 35 \mathrm{c} 50 \mathrm{lbs} \$ 1.35100 \mathrm{lbs} \$ 2.50$ Also carry a full line of Chop Feed, Corn, Oats and Bran, Get our prices.

\section{FRUIT PACKAGES}

Michigan Square Berry Boxes, crates for same, Climax Grape Baskets, Bushels, Double $\mathrm{H}$ anded Markets, Measures of all kinds. Write for prices; can make you some good ones. TOOLS AND IMPLEMENTS

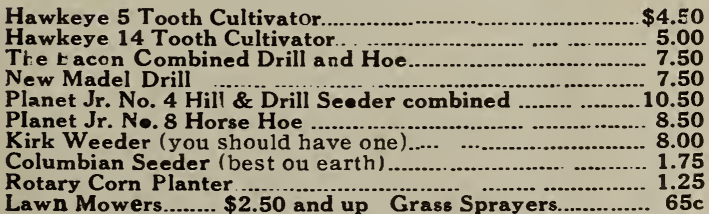

Carry a complete stock of Garden Tools, such as Hoes, Rakes, etc.. on which we are making low prices. 


\section{KEELEY CURE}

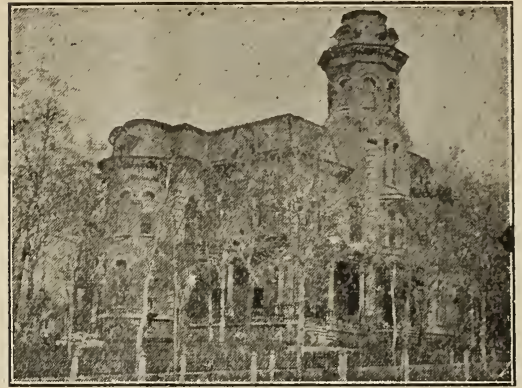

Home of the Kneley Institute, Des Moines, lowa. Established 1890
DES MOINES, IOWA, cures Liquor Naurasthema, Drug and Tobacco Addictions.

"I have influenced more than two hundred men to go to the Keeley Institute and all have come back cured. I do not think that there is any one thing that is doing the good to hum anity that the Keeley Cure is doing."-Philip D. Armour.

SEND FQR FREE BOOKLET.

Correspondence Strictly Confidential. Long Distance Telephone.

\section{Address}

Keeley Inst., Inc., 706 W. 4th St., Des Moines, Iowa.

\section{WINTER WHEAT-.-Turkish Red Wheat}

The very best variety of Winter Wheat in existence, and may be considered cirictly iron clad, as it has proven invariably so here in the most exposed !)laces every winter for sixteen years past. While it is.a Winter Wheat, not sown until September, it will pay you to order now for shipment as soon as the new crop is harvested.

Prices are somewhat subject to market, as we sell this on a close maryin, considering the extra care for seed cleaning and preparing for shipment. Send us your name now for our fall list of seeds. We will list same and take fleasure in mailing you a copy. It will save you money in buying Rye. Timcthy, Fall Wheat and other fall seeds. Write for prices on wheat.

\section{Monster Rye}

We consider Winter Rye one of the most important of all farm crops in the first place it is a sure crop-failures being almost unknown. Every farmer should have at least a few acres of it. Our "Monster Rye" is of extra quality and we are sure it will please you no matter whether you want it for pasture or a grain crop. Price, bushel, $\$ 1.00$; 5 bushels or more, $90 \mathrm{c} ; 10$ bushels or more, $75 \mathrm{c}$.

\section{Success Beardless Barley}

Earliest barley known. The straw is about the height of common barier, but better, and will stand up on any land. With good land and season has produced 80 bushels per acre. Sow as early as you can, frost does not hurt it. Many farmers will not grow barley on account of the long harsh beards which are so disagreeable in threshing, although it is a profitable crop. This is beardless and as easy to grow and handle as oats. It has hulls like the Manshure or any other old variety, and is a heavy cropper, yielding from 50 to 75 bushels per acre and the quality is excellent boih for maturing and for feed ing hogs and other stock. Seed is scarce this year. Price, by freight, bushel, $\$ 1.25 ; 2$ bushels or more, $\$ 1.20 ; 10$ bushels or more, $\$ 1.00$. Bags free.

\section{Manshure Bearded Barley}

This is an old well known six-rowed variety introduced by Professor Henry, of the Wisconsin Agricultural Experiment Station eleven or twelve years ago. It nas been worth millions of dollars to the farmers in the barley growing states. It is a barley of wonderful productiveness and is not surpassed as a heavy yielder. The "Manshure Barley" yields in ordinary seasons 60 to 6 " bishels per acre, and in favorable seasons has yielded as high as 80 bushels; figuring only 45 to 50 cents a bushel, it is one of the best paying crops. Price, 1 pound, $30 \mathrm{c} ; 4$ pounds, $75 \mathrm{c}$, by mail. By freight or express, peck, $50 \mathrm{c} ; 1$ bushel, $\$ 1.00 ; 10$ bushels or more, 85c. Bags free. 


\section{THE C. S. MARTINDALE}

\section{COMMON SENSE GATE STRONGEST GATE MADE}

If price is guarateed this $\mathrm{gate}$ will be laid down in any railruad town when two or more are ordered at a time.

Made any length or height to fit any and all pluces.

When ordering by mail be sure to give coirect dis-. tance between posts.

Correspondence solicited

All questions cheerfully answered.

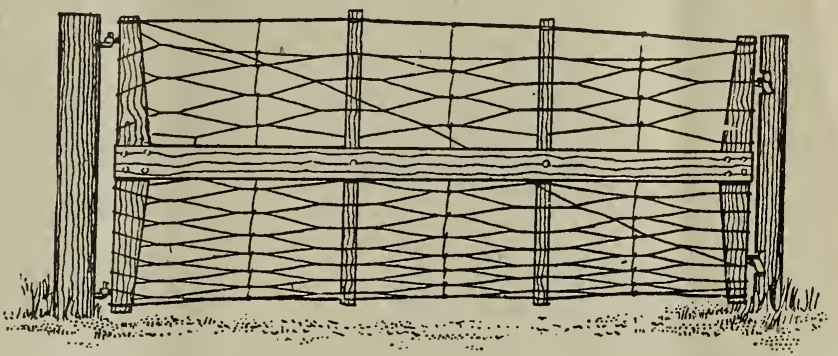

For the small sum of $\$ 5,00$ for a $10-12$ foot gate; over $12-14$ foot $\$ 550$. All gates are made $4 \frac{1}{2}$ feet high unless ordered. 'I his gate will turn any animal on the farm. And is guaranteed for one year. Is well painted and well made; of the best material to be had. Is sold Pon Honor. If broken by any stock will be replaced free of cost to purchaser. If you co not buy, you will always wish you had

Address all orders to

C. S. MARTINDALE,

One block west and north of Capitol

607 Penn Avenue

\section{Speltz}

Another very successful season of Speltz growing in this part of the country has proven without a doubt the great value of this grain. Speltz is a new grain and looks more like barley than anything else, and we have placed it among the varieties of barley. It is somewhat between a wheat and barley, the grain somewhat similar to rye when the hull or husk is removed. It is a most wonderful grain and has been introduced extensively into this country auring the past few years and has proven of great value. We have grown it here in this climate and the result has been entirely satisfactory. We beiieve it will outyield barley or oats, as it is hardier, and its feeding value is great. All who raised it enjoyed better returns than any other crop of small grain and it was easier to save during wet harvest. It is planted in early spring similar to wheat and oats, requiring about $2 \frac{1}{2}$ bushels per acre, 40 pounds per bushel. Price, 1 bushel lots, $\$ 1.00,2$ bushels or more, 90c. Write for price in quantily.

MANN'S LATEST MODEL

GREEN BONE CUTTER

\section{This illustration shows the No. 7 machine}

Price List.

No. 5-C With Crank Handle. $\$ 6.00$

No. 5-B With Balance Wheel 8.00

No. 5-BM With Balance Wheel

and Iron Stand.. 10.40

No. 7 With Balance Wheel

and Iron Stand.. 12.00

No. $71 / 2$ Semi-Power Machine 16.00

No. 9 With Balance Wheel

and Iron Stand.. 18.40

No. 12 Power Machine ... 26.00

No. 12 Power Machine ... 30.00

No. 15 Power Machine ...6 60.00

No. 14 Power Machine ...776.00

No. 18 Power Machine ....100.0u

No. 16 Power Machine ....225.00

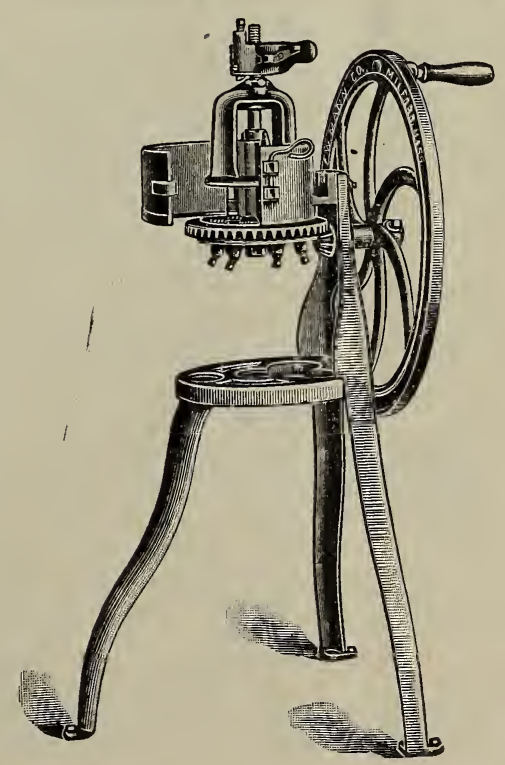




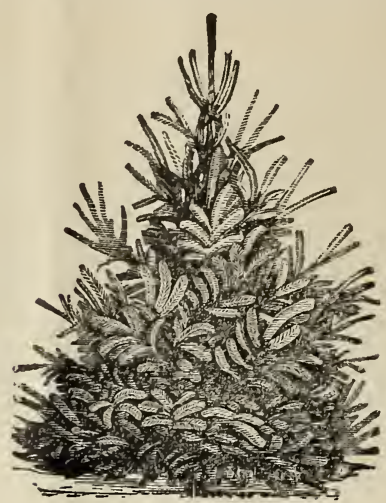

EVERGREENS.

Each Per10 Per10n Arborvitae, 2 feet....15 $\$ 1.00 \$ 8.00$ White Pine, 2 feet...25 $2.00 \quad 15.00$ Norway Spruce, 3 ft..35 $2.50 \quad 18.00$ Hemlock, 3 feet.....50 $5.50 \quad 45.00$

ROSES.

\section{Monthly Blooming.}

White, Pink, Striped, Red, Yellow. Each 10c, 5 "for 40c, postpaid.

\section{Climbing Roses.}

Crimson, Rambler, Dormant, 2-yearold.

Price, each $40 \mathrm{c}, 3$ for $\$ 1.00$, postpaid. Yellow, White and Pink same price.

Small mail order size Ramblers, each 15c, 2 for 25c, 80c per dozen.

Mary Washington Climber, each $35 \mathrm{c}$.

\section{Hardy Bush Roses.}

General Washington, White each.20c Moss Rose, Crimson, Pink or

White, each .......................

Jubilee, Dark Red, each........40c

\section{Baby Rambler Roses.}

Price, each $\$ 1.00,3$ for $\$ 2.00$, prepaid.

\section{Clematis.}

Large Flowering.

Colors White, Purple and Red,

each .....................

\section{Dahlias.}

High Grade Bulbs. Colors Pink, Crimson, White and Yellow, each 10c, 4 for $35 \mathrm{c}$.

\section{Gladiolus.} $35 \mathrm{c}$

Fine Bulbs, each 5c, 3 for $10 \mathrm{c}$, doz.,

\section{Tube Roses.}

Choice Bulbs, each 5c, 3 for $10 \mathrm{c}$, doz., 30c.

\section{Chrysanthemums.}

Strong Plants, each $10 \mathrm{c}, 3$ for $25 \mathrm{c}$ doz., $80 \mathrm{c}$.

Tulips. paid.

Single or Double, per doz., 40c, pre-

\section{Cinnamon Vine.} $75 \mathrm{c}$.

A Handsome Climber, each $10 \mathrm{c}$, doz., Honeysuckle.

Hall's Japan, each 25c, 3 for 60 c.

\section{Paeonies.}

Double Mixed, each 20c, doz., \$1.75. Crocus.

Choice Mixed, doz., 25c, 3 doz., 60c. English Ivy.

Climbing Vine, each 10c, 3 for $25 \mathrm{c}$, doz. $80 \mathrm{c}$.

\section{German Ivy.}

Climbing Vine, each $10 \mathrm{c}, 3$ for $25 \mathrm{c}$, doz., 80c.

\section{Crown of Thorns.}

Very Curious, each 25c, 3 for $60 \mathrm{c}$, doz., $\$ 1.75$.

\section{Cactus.}

Very Odd, Cactus Family of $10, \$ 7.00$ Snowball.

1 Year Old Shrub, each 25c, 3 'for $65 c$.

\section{Lilac.}

Purple, each 25c, 3 for 60c.

Whiıe, each j0c, \& for $\$ 1.25$.

\section{Palms.}

Latania Borbonica, each $30 \mathrm{c}, 3$ for 75 c.

Sword Leaf, each 20c, 3 for 50 c.

\section{Callas.}

Little Gem, White, each 10c, 3 for 25c.

Spotted, each $-15 \mathrm{c}, 3$ for $40 \mathrm{c}$.

\section{Lily of the Valley.}

Nice Pipes, doz., 45c, 6 for $25 \mathrm{c}$, each 5c.

\section{Fuchsias.}

Jupiter, each 15c, 2 for $25 \mathrm{c}$, doz 80 c. Geraniums.

Ruyblas, each 20c, 2 for $35 \mathrm{c}$, doz., $\$ 1.00$.

\section{Carnations.}

Mixed Colors, doz., 75c, 6 for $40 \mathrm{c}$, each 10c. 


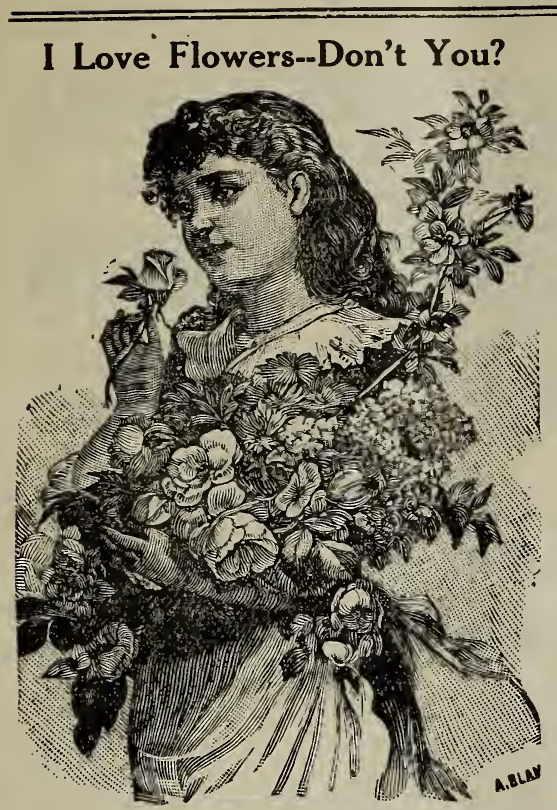

The following is a standard list of High Grade Flower Seeds at 1 2, and 3 cents per packet. ASTERS.

Pkt. Oz.

Choice Mixed ........... 5

ALYSSUM.

Little Gem ............ 2

\section{BALSAM.}

Double Flowering ........ 3 BACHELOR BUTTONS.

Fine Mixed ............ 3 CARNATIONS.

Double Mixed ............5 CANDY TUFT.

Sweet Scented ..........2 CELOSIA.

Coxcomb ..............5 CASTOR BEANS.

Tall ................. 1 CYPRESS VINE.

Choice Mixed Red, White and Yellow .............. 5 FOR GET ME NOT.

Fine Blue ............. 5 FOUR O'CLOCK.

Choice Mixed ..........4 4 HOLLYHOCK.

Fine Mixed Double ........ 5 MORNING GLORY.

$\mathrm{Mi}_{\mathrm{X}} \mathrm{ed} \ldots \ldots \ldots \ldots \ldots \ldots \ldots 1$ MARIGOLD.

American Mixed .........1 MIGNONETTE.

Sweet

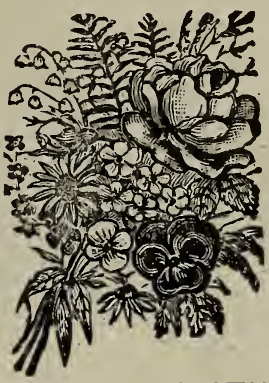

A PACKAGE o'f Mixed Flower Seeds, con. taining $\quad 300$ kinds of choice Annual Bloom. i $\mathbf{n g}$ Flowers for only 5 cents, 3 for 10 cents. Don't forget it.

NASTURTIUM.

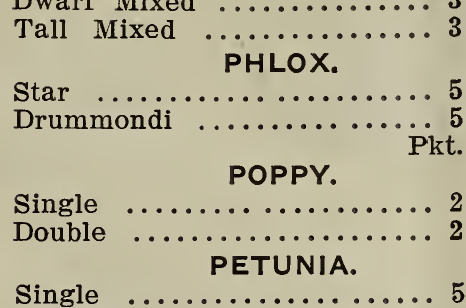

Double $\ldots \ldots \ldots \ldots \ldots \ldots \ldots \ldots \ldots \ldots 10$

PARTULACCA.

Single Mixed ........... 5

Double Mixed $\ldots \ldots \ldots \ldots \ldots \ldots 10$

PANSY.

Common .............. 5

Large German ............10

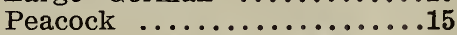

SWEET PEAS.

Choice Mixed ............ $3 \quad 5$ VERBENA.

Choice $\ldots \ldots \ldots \ldots \ldots \ldots \ldots \ldots .5$ ZINNIA.

Choice Mixed ........... 5

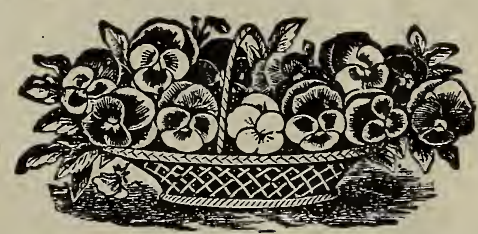

A BASKET OF PEACOCK PANSIES. Our Flower Seed Collection BEATS THEM ALL

25c FLOWER SEEDS 25c

One packet of each of the following flower seeds sent postpaid to any ad. dress for only $25 \mathrm{c}$ :

Asters Petunia, mixed

Bachelors Button Pansy, mixed

Candytuft $\quad \mathrm{Phlo}_{\mathrm{X}}$

Nasturtium Sweet Peas

Mignonette Verbena

This is absolutely the best collec10 tion ever offered. 


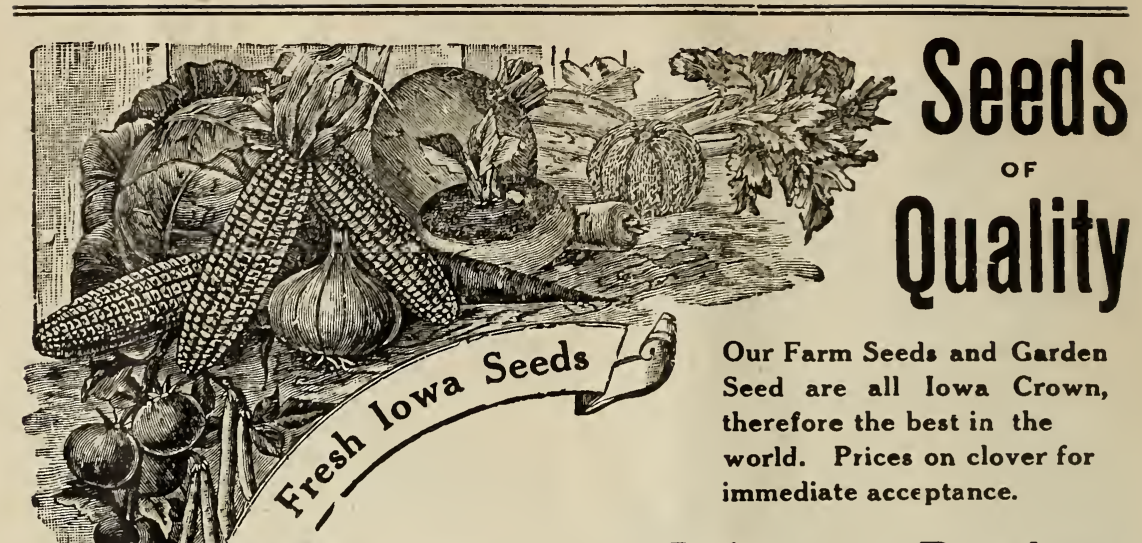

\section{Special Price to Dealers}

\section{Samples gladly sent on application}

ASPARAGUS.

CELEP.Y.

Pkt. Oz. Ib.

Columbian, Mam, white.... 3 '5 4"I

Two year old Asparagus Roots, $\$ 1.00$ per 100 .

\section{DWARF BEANS.}

Pt. Pt. Qt. Bu.

German Black Wax.10 $18 \quad 28$ \$2

Golden Wax .......12 $20 \quad 30 \quad 2.30$

Stringless Green Pod $12 \quad 20 \quad 30 \quad 2.30$

Henderson's Bush

Lima ..........12 $20 \quad 30 \quad 3.25$

POLE BEANS.

Kind of Garden $1 / 2$
Pt. Pt. Qt. Bu.

Lima $\ldots \ldots \ldots \ldots 12 \quad 20 \quad 30 \quad \$ 2.25$

Dutch Case Knife...12 $20 \quad 30 \quad 2.00$

$\begin{array}{lllll}\text { Cut Short } \ldots \ldots \ldots 12 & 20 & 30 & 2.00\end{array}$ CRESS. Pkt. Oz. $1 / 4$ ib ib Green Curled ........ $3 \quad 5 \quad 15 \quad 40$ SWEET CORN.

Pt. Pt. Qt. Bu.

Early Sunrise ......10 $15 \quad 25 \quad \$ 1.25$

$\begin{array}{lllll}\text { Dwarf Evergreen . . . } & 8 & 12 & 20 & 1.00\end{array}$

Early Minnesota .... $88 \quad 15 \quad 20 \quad 1.00$

Mammoth Evergreen $8 \quad 15 \quad 20 \quad 1.75$

Stowells Evergreen. $8 \quad 15 \quad 20 \quad 1.75$

BEETS.

Pkt. Oz. $1 / 4$ tb tb

Market Garden ....... $3 \quad 5 \quad \begin{array}{llll}12 & 35\end{array}$

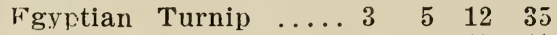

Detroit Turnip ....... $4 \quad 7 \quad \begin{array}{llll} & 15 & 40\end{array}$

$\begin{array}{llllll}\text { Early Blood Turnip .. } & 3 & 5 & 12 & 30\end{array}$

Long Smoot Red .... $4 \begin{array}{llll}7 & 15 & 40\end{array}$

Mango Wurzle ....... 2 $5 \quad 7 \quad 20$

\section{CAULIFLOWER.}

Pkt. Oz. $1 / 4$ it it

Farly Snowball ...... $5 \$ \$ 1.60$

Late Lamburt ...... $4 \quad 1.50$
Pkt. Oz. $1 / 4$ it its

White Flime ........ $3 \quad 12 \quad 35 \quad 90$

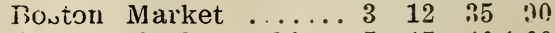

Golden Se.f-Blanching. $5 \quad 15 \quad 401.00$ CARROTS.

Pkt. Oz. $1 / 4 \mathrm{Ib}$ Ib

Ox Heart ........... $355^{2} 12$ 4.

Denver Half Long .... $35 \quad 5 \quad 12 \quad 45$

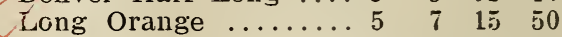

CABBAGE.

Pkt. Oz. $1 / 4$ tb. It

Green Cluster .........2 $8 \quad 20 \quad 75$

Long Green ........... $3 \quad 10 \quad 25 \quad 85$ CUCUMBER.

Pkt. Oz. $1 / 4$ to th

Farly Fourth of July. $5 \quad 12 \quad 45 \$ 1.40$

Early York ......... $3 \quad 10 \quad 40 \quad 1.25$

Wash'yton Wakesfield $4 \quad 11 \quad 45 \quad 1.40$

Premium Flat Dutch . $3 \quad 10 \quad 40 \quad 1.25$

Mam. Autumn King. $\quad 5 \quad 15 \quad 50 \quad 1.50$

EGG PLANT. ... . . .

Pkt. Oz. ${ }^{1 / 4}$ Ib.

White Pearl ............ $20 \quad 75$

New York Imp............ 520 75

N. Y. Round Purple ..... $5 \quad 5 \quad 20 \quad 75$ ENDIVE.

Moss Curled ............. $5{ }^{`} 10 \quad 30$

Broad Leaved ........... $5 \quad 10 \quad 25$ GOURDS.

Nest Egg .............. $5 \quad 15 \quad 40$

Sugar Trough ............ 5 5 $10 \quad 30$

Dipper .............. $5 \quad 10 \quad 30$

WATER MELONS.

Ice Cream .......... $3 \quad 5 \quad 15 \quad 40$

Coles Early .......... $3 \quad 5 \quad 15 \quad 40$

Kolbs Gem ........... $3 \quad 5 \quad 1540$

G^orge Rattlesnake.... $3 \quad 5 \quad 15 \quad 40$

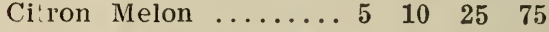

MUSK MELON.

Pkt. Oz. ${ }^{1} 4$ lb it.

Rockford ........... $3 \quad 7^{2} \quad 20 \quad 50$

Round Nutmeg ....... $3 \quad \begin{array}{llll}7 & 15 & 40\end{array}$

Netted Gem .......... $3 \quad 7 \quad 15 \quad 40$ 
KOHL RABI.

Purple Vienna .........5 50 .31 - Scarlet Turnip Pkt. Oz. $1 / 4$ it it

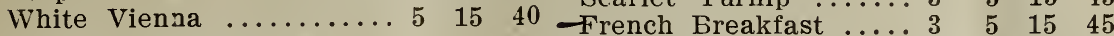

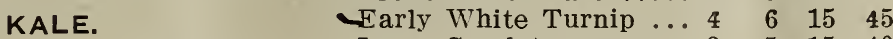

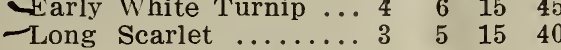

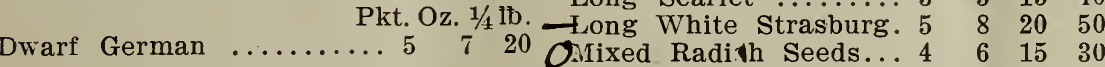

\section{LETTUCE.}

Pkt. Oz. $1 / 4$ tb it

Prize Head .......... $3 \quad 8 \quad 25 \quad 80$

Green Fringed $\ldots \ldots \ldots .3 \quad 8 \quad 8 \quad 25 \quad 80$

Denver Market Head.. $3 \quad 3 \quad 8 \quad 25 \quad 80$

LEEK.

American Flag ...... $5 \quad 10 \quad 30$

MUSTARD.

Pkt. Oz. $1 / 4$ tb tb

White English $\ldots \ldots \ldots 55^{8} \quad 8^{2} 30$

Green Curled ......... 5 5 8 $15 \quad 35$

ONIONS.

Pkt. Oz. $1 / 4$ tb tb

$\checkmark$ Red Weahersfield $\ldots . .3 \quad 3 \quad 7 \quad 20 \quad 75$

$\checkmark$ Prize Taker ......... $3 \quad 10 \quad 25 \quad 90$

Silver King ........... $3 \quad 12 \quad 301.10$

ONION SETS.

Pkt. Oz. $1 / 4 \mathrm{Ib}$ ib

Red $\ldots \ldots \ldots \ldots \ldots 10 \quad 20 \quad 90 \$ 2.90$

White.................

Yellow $\ldots \ldots \ldots \ldots \ldots 10 \quad 20 \quad 75 \quad 2.75$

PEPPERS.

Pkt. O " " "

Ruby King .........5 5 15 40

Golden Queen ........ $5 \quad 5 \quad 20 \quad 5,0$

Cyenzie ............ $5 \quad 30 \quad 60$

PARSLEY.

Large Hamburg ..... 5 \& 20

PUMPKIN.

Sweet $r r$ Pie $\ldots \ldots \ldots 5 \%$ \& $15 \quad 40$ Commion Field ......2 5 5 10,20

PARSNIPS.

Long Sugar ......... $\quad \begin{array}{llll}5 & 12 & 30\end{array}$

Table Guernsey ....... 5 \& $\$$ \& 1540

PEANUTS.

Red Cross $\ldots \ldots \ldots \ldots .5 \% \quad 7 \quad 10 \quad 25$

VINE PEACH.

Or Mango Melon.

Smooth Yellod ......: $5 \quad 10 \quad 351.00$

PEAS.

Pt. Pt. Qt. Bu.

Little Gem ........10 15 25 $\$ 1.75$

American Wonder ..10 $15 \quad 30 \quad 2.00$

Fremium Gem ......10 $15 \quad 25 \quad 1.80$

$\begin{array}{lllll}\text { Alaska } \ldots \ldots \ldots \ldots 10 & 15 & 25 & 1.60\end{array}$

$\begin{array}{llll}\text { Champion of Engl'nd } 12 \quad 20 & 30 & 2.00\end{array}$

I.arge White Marrow-

fats $\ldots \ldots \ldots \ldots \ldots 15 \quad 25 \quad 40 \quad 2.25$
WINTER SORTS.

I.arge Black Spanish.. $5 \quad 7 \quad \begin{array}{llll}18 & 50\end{array}$

Chinese Rose ........ $4 \quad 6 \quad 15 \quad 45$

\section{RHUBARB.}

Victoria ........... $5 \quad 15 \quad 30$

Linnaeans $\ldots \ldots \ldots \ldots \ldots 5 \%$

RUTABAGA.

Am. Yellow Purpletop. $3 \quad 5 \quad 15 \quad 30$ SALSIFY.

Pkt. Oz. $1 / 4$ tb ib

Sandwick Island ...... $5 \quad 10 \quad 25 \quad 75$

Long White ......... 5 5 $10 \quad 25 \quad 75$

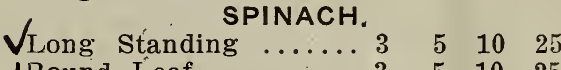

JRound. Leaf ............ $3 \quad 5 \quad 5 \quad 10 \quad 25$

SQUASH.

Plkt. Oz. $1 / 4$ to to

True Hubbard ....... $5 \quad 5 \quad 10 \quad 30 \quad 90$

Sibley ............ $5 \quad 5 \quad 12 \quad 351.00$

White Bush ........4 $4 \quad 8 \quad 25 \quad 75$

Yellow Bush ............4 $4 \quad 8 \quad 25 \quad 75$ Grv TURNIP.

Pkt Oz. $1 / 4$ ib ib

Purple Top Strap Leaf. $3 \quad 5 \quad 153$ כ TOMATO.

Pkt. Oz. $1 / 4$ ito

Red Beauty ............. 320 50

Ferris Wheel ...........4 $420 \quad 50$

Dwarf Champion ........... 4 $420 \quad 50$

Imp. Tree ............ $4 \quad 20 \quad 50$

Golden Queen Yellow .... $5525 \quad 60$

Matchless Large Red ...... $5 \quad 25 \quad 70$ Tomato Plants in Season.

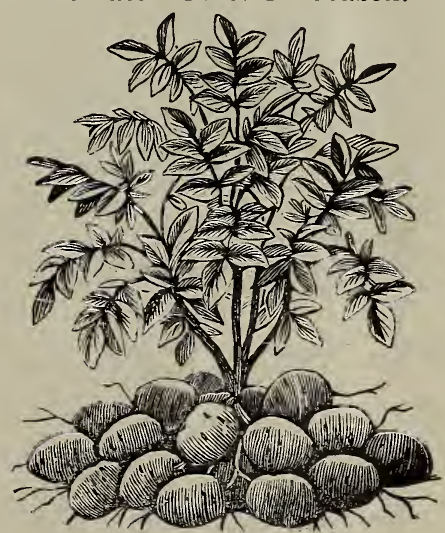

A Hill of Early Six Weeks' Potatoes. SEED POTATOES.

$\mathrm{Pk} 1 / 2 \mathrm{bu} \mathrm{Bu} 3$ to 5 bu

Early Six Weeks..40 $60 \quad 1.00$ At 90

Early Ohio .......40 $60 \quad 1.00$ At 90

Bonanza ........35 $50 \quad .90$ At 80 


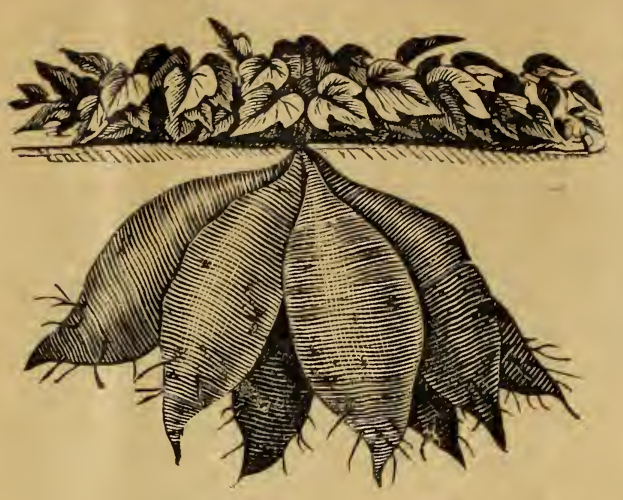

Early Yellow Jerseys. SEED SWEET POTATOES.

Yellow Jersey .......Write for Prices Red Jersey .........Write for $\cdot$ Prices Sweet Potato Plants in Season.

$\begin{array}{rrrr}100 & 1,000 & 5,000 & 10,000\end{array}$

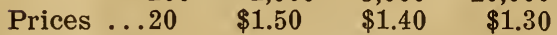

A Wonderful Collection 25c GaRDEN SeEDS $25 c$

One pkt. of each of the following sent prepaid to any address upon receipt of 25c. You can't miss this:

Beans, Golden Wax

Beets, Blood Turnip

Lettuce, Prize Head

Water Melon, Ice Cream

Musk Melon, Rockeyford

Onion, Weathersfield

Parsnips, Long Sugar

Peas, Little Gem

Radish, Scarlet Turnip

'Turnip, Purple Top

Positively no changes made in the above collection.

\section{Where Shail I Co?}

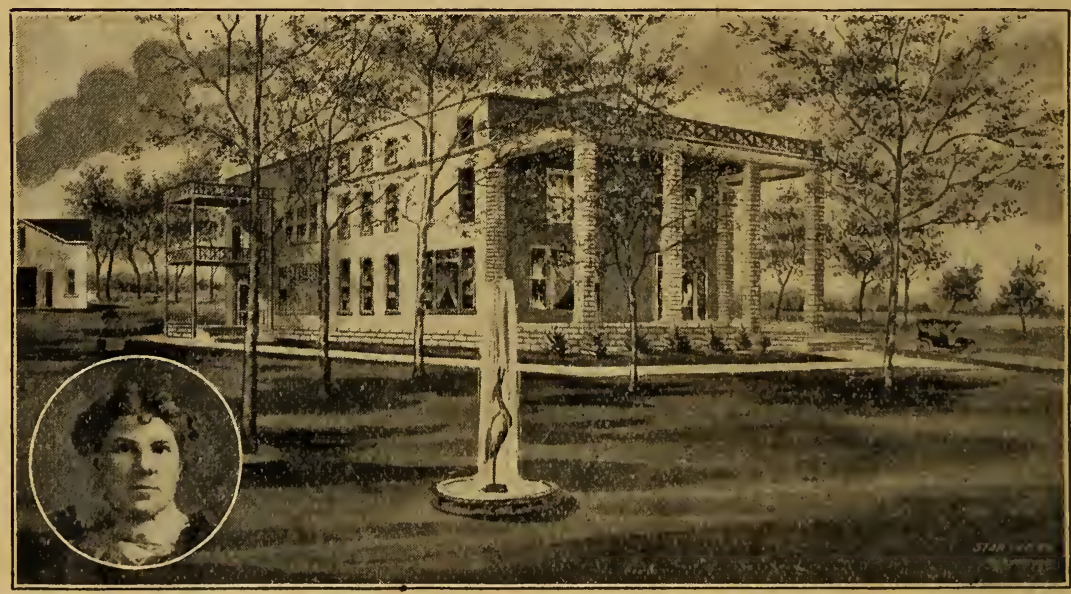

\section{To Mrs. West's Maternity Home}

This new hospital just unished is the finest and best equipped home of its kind in the west. Everything is modern and up-to-date.

No finer place for unfortunate girls or married women, where they will have the best medical attention, good board and rooms.

Prices in reach of all. Work furnished to help pay expenses when needed.

Mrs. West is certainly a friend to the unfortunate.

Babies adopted ir. good Christian homes.

Take a Cab at the Depot for 1314 35th Street, Des Moines, lowa 


\title{
CLIMBING CURRAN'T
}

\section{THE GREATEST WONDER OF THE AGE}

Photo of plant 5 years old.

\author{
14 feet high, 8 feet wide
}
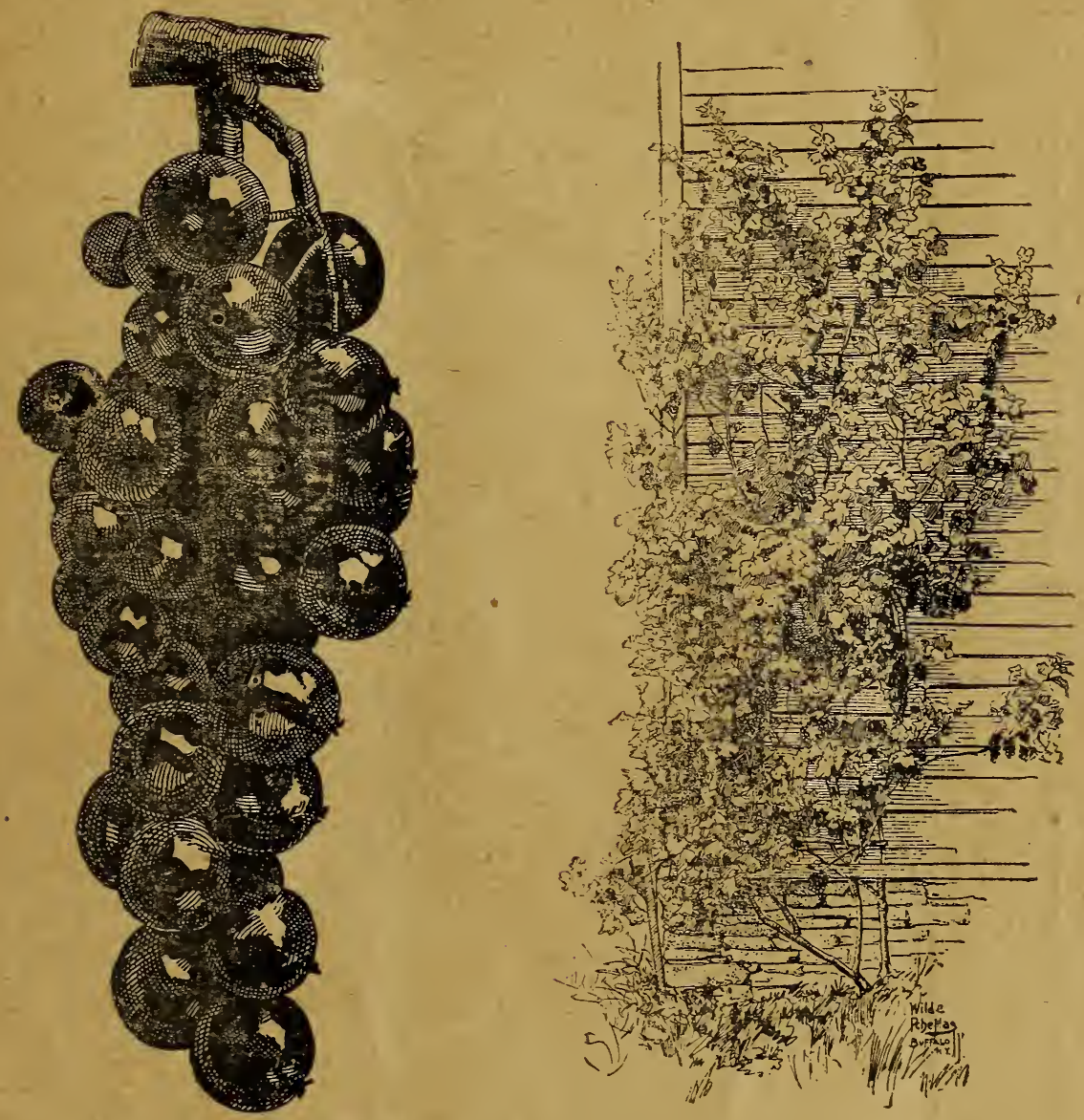

Send us an "order for one or two plants. Give them good care and cultivation and you will never regret it. We sent out several hundred plants last season and not one single complaint of poor plants or bad eondition. We fully understand packing and will use care in same.

The greatest novelty In the world and the most reliable bearing currant known. You should try one or two of them. They are hardy outdoor plant. Prlce each 75 cents, 2 for $\$ 1.25$, prepaid. 


\section{Beautiful Rugs}

\section{made from \\ OLD CARPETS}

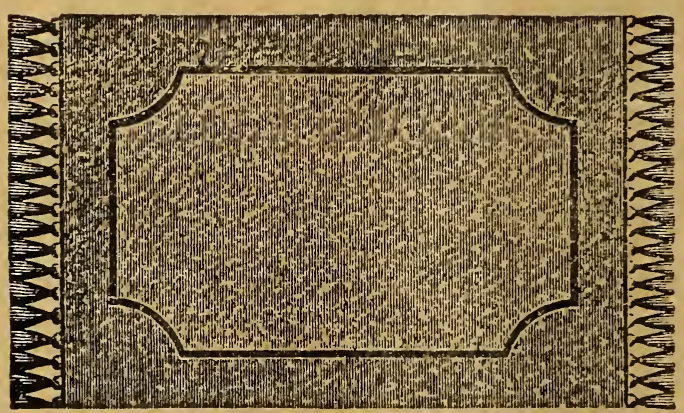

"Curved Corner Border all Around."

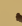

We make any sized rug from 18 inches to 12 feet in width and any desired length. We pay the freight on your old carpet and guarantee satisfaction.

Write a postal for Prices.

\section{lowa Rug Co. DES MOINES, IOWA} 2022 COTTAGE GROVE 